University of New Orleans

ScholarWorks@UNO

Department of Economics and Finance Working

Papers, 1991-2006

Department of Economics and Finance

2004

\title{
Re-examining inflation and inflation uncertainty in developed and emerging countries
}

\author{
Elton Daal \\ University of New Orleans \\ Atsuyuki Naka \\ University of New Orleans \\ Benito Sanchez \\ University of New Orleans
}

Follow this and additional works at: https://scholarworks.uno.edu/econ_wp

\section{Recommended Citation}

Daal, Elton; Naka, Atsuyuki; and Sanchez, Benito, "Re-examining inflation and inflation uncertainty in developed and emerging countries" (2004). Department of Economics and Finance Working Papers, 1991-2006. Paper 26.

https://scholarworks.uno.edu/econ_wp/26

This Working Paper is brought to you for free and open access by the Department of Economics and Finance at ScholarWorks@UNO. It has been accepted for inclusion in Department of Economics and Finance Working Papers, 1991-2006 by an authorized administrator of ScholarWorks@UNO. For more information, please contact scholarworks@uno.edu. 


\title{
Re-examining inflation and inflation uncertainty in developed and emerging countries
}

\author{
Elton Daal, Atsuyuki Naka and Benito Sanchez \\ Department of Economics and Finance \\ University of New Orleans \\ Lakefront, New Orleans, LA70148
}

\begin{abstract}
This study examines the relationship between inflation and inflation uncertainty for both developed and emerging countries using the asymmetric power GARCH model. We find new evidence that suggests that positive inflationary shocks have stronger impacts on inflation uncertainty for mainly Latin American countries. We also find that inflation causes inflation uncertainty for most countries but the evidence for causality of the opposite direction is mixed.
\end{abstract}

JEL classification: C22; E31

Corresponding Author:

Atsuyuki Naka

Department of Economics and Finance, University of New Orleans

Lakefront, New Orleans, LA70148

Tel: 504 280-6896; fax: 504 280-6397. E-mail address: anaka@uno.edu 


\section{Introduction}

Economists have long studied the relationship between inflation and inflation uncertainty because of its central importance on policy analysis. Cukierman and Meltzer (1986) hypothesize that inflation uncertainty leads to higher average inflation rates due to opportunistic behavior of central banks that are motivated by expansionary policies. In contrast, Ball (1992) argues that higher inflation rates create higher inflation uncertainty. According to Friedman (1977), high inflation will create political pressure to reduce it, but policy makers may fear recessionary effects and therefore be reluctant to lower inflation, resulting in future inflation uncertainty.

There are extensive empirical studies that examine the relationship between inflation and inflation uncertainty, of which the majority rely on time-series analyses. Recent studies that use a generalized autoregressive conditional heteroskedastic (GARCH) type of model include Grier and Perry (1998), Nas and Perry (2000), Davis and Cango (2001), Fountas (2001), Hwang (2001), Apergis (2004), and Kontonicas (2004), among others. Most studies however examine a selective group of countries. ${ }^{1}$ A GARCH model will estimate timevarying residual variances as proxy for unexpected inflation volatility. As Grier and Perry (1998) point out, a GARCH method provides parametric tests of uncertainty and allows us to test for causality relationship between inflation and inflation uncertainty.

The current paper offers a comprehensive examination of the relationship between inflation and its uncertainty. We re-examine this relationship for both developed and emerging countries and allows for asymmetric inflation uncertainty by using the asymmetric

\footnotetext{
${ }^{1}$ Davis and Kango (2001) provide an extensive review of studies dealing with issues of inflation and inflation uncertainty, and examine inflation uncertainty for the OECD countries.
} 
power GARCH (PGARCH) specification. The PGARCH provides a relatively parsimonious specification to capture time-varying inflation uncertainty, asymmetric effects, and clustering in the conditional variances of the inflation rates. Existing literature has not yet addressed broad geographical categories of countries that include both developed and emerging markets. We include in this study G7 countries and emerging markets from Asian, Latin American, and Middle Eastern countries. We use updated long-term time series data that cover monthly inflation rates from January 1957 to May 2005.

This study provides new evidence that suggests that positive inflationary shocks have stronger impacts on inflation uncertainty for mainly Latin American countries. We also document that inflation Granger causes inflation uncertainty for most of the countries examined for different time periods with different lag structures, but the evidence for causality of the opposite direction is mixed. The Friedman-Ball hypothesis is strongly supported, while the evidence for the Cukierman and Meltzer hypothesis (1986) depends on the country examined, and the time periods and lag structures.

\section{Methodology and Data:}

\subsection{Estimating Inflation Uncertainty and Testing the Causality:}

The PGARCH is used to obtain time-varying residual variances as a proxy for inflation uncertainty. Ding, Granger and Engle (1993) originally proposed the model and examined the volatility of S\&P500 index returns. Heston and Nandi (2000) used PGARCH to investigate S\&P500 index options. The following ARMA(p, $(1,12))-\operatorname{PGARCH}(1,1)$ model is estimated for each country:

$$
\begin{gathered}
\pi_{t}=a_{0}+a_{1} \pi_{t-1}+a_{2} \pi_{t-2}+\ldots+a_{p} \pi_{t-p}+d D_{t}+\varepsilon_{t}+\theta_{1} \varepsilon_{t-1}+\theta_{2} \varepsilon_{t-12} \\
h_{t}=\alpha_{0}+\alpha_{1}\left(\left|\varepsilon_{t-1}\right|-\psi \varepsilon_{t-1}\right)^{\delta}+\beta_{1} h_{t-1}
\end{gathered}
$$


where $\pi$ denotes inflation rate, $D$ is a dummy variable with one for the extremely high inflation rates (one percent of the highest observations) and zero for otherwise, $\varepsilon$ is an error term. ${ }^{2}$ Fountas (2001) uses dummy variables to capture structural breaks during the high inflation periods using annual data for the U.K. and Hwang (2001) incorporates dummy variables for the U.S.

The MA $(1,12)$ specification gives us parsimonious estimation by reducing the order of the AR processes and capturing potential seasonality in data. For example, Grier and Perry (1998) do not add MA processes, but instead use AR(12) processes with eleven dummies to capture seasonality. ${ }^{3}$ The parameter $\psi$ captures the asymmetric effect of inflation uncertainty and $\delta$ is a Box-Cox power transformation parameter. As illustrated by Ding, Engle and Granger (1993), if $\psi$ is negative, then positive shocks increase the volatility more than negative shocks do. In this paper, we set $\delta=2$ to reduce the number of parameters that has to be estimated. ${ }^{4}$ We use Akaike Information Criterion (AIC) and Schwartz Bayesian Criterion (SBC) to determine the length of the AR process and Lagrange Multiplier (LM) to test for the presence of an ARCH process.

A vector autoregression model (VAR) is used to test whether inflation $\left(\pi_{t}\right)$ Granger causes inflation uncertainty $\left(h_{t}\right)$ or vise versa. The following bivariate VAR is estimated:

\footnotetext{
${ }^{2}$ We also estimate the model by assigning dummy variables with different standard deviations (3.0 and 3.5$)$ to deal with the potential outliers and structural breaks. The properties of stationarity and parameters estimated will change for some of countries but the main results are intact.

${ }^{3}$ Refer to Enders (Chapter 2, 2004) on this issue.

${ }^{4}$ This specification will not alter the empirical implication of our study. Heston and Nandi (2000) set the parameter equals to 2 for their study and Ding, Engle and Granger (1993) obtain $\delta=1.43$.
} 


$$
\begin{aligned}
& h_{t}=\gamma_{0}+\sum_{i=1}^{k} \gamma_{1 i} h_{t-i}+\sum_{i=1}^{k} c_{1 i} \pi_{t-i}+e_{1 t} \\
& \pi_{t}=\gamma_{1}+\sum_{i=1}^{k} \gamma_{2 i} h_{t-i}+\sum_{i=1}^{k} c_{2 i} \pi_{t-i}+e_{2 t}
\end{aligned}
$$

We test the statistical significance of overall (positive or negative) effects of the causality between $\pi_{t}$ and $h_{t}$ by using F-tests. For robustness, we examine the causality relationships for 4, 8 and 12 lags.

\subsection{Data Description:}

Monthly inflation rates are based on the log differences from consumer price index (CPI) data obtained from the International Financial Statistics (IFS) CD-ROM. We study twenty-three countries over varying time periods, the majority of which span from February 1957 to May 2004 for a maximum of 568 monthly observations. Bahrain, which is the smallest of our sample countries, has the shortest time period, beginning in August 1975 with 314 observations. $^{5}$

\section{[Insert Table 1 here]}

Table 1 presents the summary statistics. Argentina has the highest average monthly inflation rate of $5.25 \%$ (or $63 \%$ annual rate), followed by Peru with a $3.83 \%$ inflation rate. Notice that Peru experienced the highest inflation rate of over $160 \%$ a month! Germany indicates the lowest average inflation with a monthly rate of $0.24 \%$ (less than a $3 \%$ annual rate). Overall, Latin American countries exhibit the highest inflation rates with the largest standard deviations and, as expected, the G7 countries display both the lowest inflation rates and standard deviations.

\footnotetext{
${ }^{5}$ Although we originally examined nine more countries, they are omitted from this study because of nonstationary inflation rates or problems of convergence.
} 


\section{Empirical Results}

\subsection{Estimates of Inflation Uncertainty:}

Inflation rates are stationary at a one percent significance level for fourteen countries, at a five percent for six countries and at a ten percent for two countries. The LM tests indicate the presence of ARCH effects for all countries (not reported) ${ }^{6}$. Panels A and B in Table 2 present the estimation results of the mean equations (ARMA) and inflation uncertainty $(\mathrm{PGARCH})$. Adding $\mathrm{MA}(1,12)$ substantially reduces the order of the AR component. For all countries, based on the SBC, the order of the AR process of the mean equations does not exceed seven. ${ }^{7}$ All coefficients of the $12^{\text {th }}$ lag of the MA process are significant at a one percent level, suggesting the presence of seasonality in the data. Also, the dummy variables are significant at a one percent level for all countries. Consistent with Nas and Perry (2000), we find that coefficients of AR(1) and MA(12) are significant for Turkey.

[Table 2 here]

Panel B in Table 2 shows the PGARCH estimation results. The parameter $\alpha_{1}$ is significant at a 10 percent or higher level (except Japan) and $\beta_{1}$ is significant for all countries at a level of at least one percent (five percent for Germany). However, the asymmetric effects of the time-varying conditional heteroskedasticity differ across regions. For all of the Latin American countries, which have the highest inflation rates and standard

\footnotetext{
${ }^{6}$ We use Akaike Information Criterion 2 (AIC2) to decide the optimal lags for the ADF tests. Following Pantula et al. (1994), the optimal lag is selected such that: $L A G=M I N(j+2$, MAXLAG), where $j$ is the number of lags that minimizes AIC.

${ }^{7}$ The orders of the AR process are much longer and some exceed 12 when we exclude the MA process in the equation (1).
} 
deviations, and four other countries India, the U.K., Egypt, and Morocco, the parameters of $\psi$ are statistically significant at five percent or higher with a negative sign. Statistically significant negative coefficients of $\psi$ suggest that positive inflationary shocks result in stronger effects on inflation uncertainty for these countries. ${ }^{8}$

\subsection{Causality Relationships between Inflation and Inflation Uncertainty:}

In Table 3, we find that inflation Granger causes inflation uncertainty for almost all of the countries and the results are robust for different lags and sub-periods (most notable exception is Germany). The aggregated effects are positive and statistically significant at a one percent level for all Asian countries, five G7 countries, the Latin American countries (except for Peru), and all Middle Eastern countries. We also test for the first sub-period, 1957-1980 and the second sub-period, 1981-2004. Although the results differ for some of countries, overall our findings are consistent across the sub-periods (not reported). We note that the total effect of Germany is an anomaly. It is positive and statistically significant during the first sub-period, but negative during the second sub-period. The results may be attributed to traditionally strong anti-inflationary policy imposed by the German Central bank.

[Table 3 here]

The results of causality from inflation uncertainty to inflation are mixed. The hypothesis by Cukierman and Meltzer (1992) can be partially supported. Signs depend on countries examined and roughly one half of them are significant. Among the G7 countries, significant positive effects are found for Germany, Italy and Japan but negative effects (not

\footnotetext{
${ }^{8}$ According to Ding, Granger, and Engle (1993), the stability of PGARCH is obtained when $\alpha_{1}\left(1+\psi^{2}\right)+\beta<1$. The estimated PGARCH processes are stationary for all countries (although some are close to one).
} 
significant) exist for Canada and France, and there are mixed signs for the U.K. and U.S. Grier and Perry (1998) report positive effects for France and Japan, negative for Germany and the U.S., and mixed results for Italy. We interpret the negative sign as evidence of stabilization behavior in these countries because increased inflation uncertainty lowers average inflation as argued by Holland (1995) in the U.S. Our findings basically agree with the recent study by Apergis (2004), who finds support of Friedman-Ball hypothesis but mixed results for the other direction for G7 countries. Hwang (2001) finds that a higher inflation rate reduces its conditional variance in the U.S.; however, the results are rather weak and depend on the model specifications. Kontonicas (2004) finds a positive relationship between inflation and inflation uncertainty based on various GARCH specifications for the U.K.

\section{Concluding Remarks}

In this study, we have re-examined the relation between inflation and inflation uncertainty for both developed and emerging countries using the asymmetric power GARCH model. We find evidence that positive inflationary shocks have stronger impacts on inflation uncertainty for mainly Latin American countries. We also find that inflation Granger causes inflation uncertainty for most countries for different time periods with different lag structures, but the evidence for causality of the opposite direction is mixed. Our findings strongly support the Friedman-Ball hypothesis for both developed and emerging countries, and they are consistent with existing research. 


\section{References}

Apergis, Nicholas, 2004, Inflation, output growth, volatility and causality: Evidence from panel data and the G7 countries, Economics Letters, 83, 185-191.

Ball, Laurence, 1992, Why does high inflation raise inflation uncertainty?, Journal of Monetary Economics, 29, 371-388.

Cukierman, Alex, and Alan Meltzer, 1986, A Theory of Ambiguity, Credibility, and Inflation Under Discretion and Asymmetric Information, Econometrica, 54, 1099-1128.

Davis, K. George and Bryce E. Kango, 2001, The level and uncertainty of inflation: results from OECD forecasts, Economics Inquiry 38, 58-72.

Ding, Zhuanxin, Clive W.J. Granger and R.F. Engle, 1993, A long memory property of stock market returns and a new model, Journal of Empirical Finance, 1, 83-106.

Enders, Walter, 2004, Applied Econometric Time Series, John Wiley \& Sons, Inc.

Fountas, Stilianos, 2001, The relationship between inflation and inflation uncertainty in the UK: 1885-1998, Economics Letters 74, 77-83.

Friedman, Milton, 1977, Novel Lecture: Inflation and unemployment, Journal of Political Economy, 85, 451-472.

Grier, Kevin B., and Mark J. Perry, 1998, On inflation and inflation uncertainty in the G7 Countries, Journal of International Money and Finance, 17, 671-689.

Heston, L. Steven and Saikat Nandi, 2000, A closed-from GARCH option valuation model, Review of Financial Studies, 13, 585-625.

Holland, A. Steven, 1995, Inflation and uncertainty: tests for temporal ordering, Journal of Money, Credit and Banking, 27, 827-837.

Hwang, Y., 2001, Relationship between inflation and inflation uncertainty, Economics Letters 73, 179-186.

Kontonicas, A., 2004, Inflation and inflation uncertainty in the UK evidence from GARCH modeling, Economic Modeling 21, 524-543.

Nas, F. Tevfik and Mark J. Perry, 2000, Inflation, inflation uncertainty, and monetary policy in Turkey: 1960-1998, Contemporary Economic Policy 18, 170-180.

Pantula, S.G., Graciela Gonzalez-Farias, and Wayne Fuller, 1994, A comparison of unitroot test criteria, Journal of Business and Economics Statistics, 449-459. 
Table 1. Summary Statistics

\begin{tabular}{|c|c|c|c|c|c|c|}
\hline Country & Nob & Average & $\begin{array}{r}\text { Standard } \\
\text { Deviation }\end{array}$ & Min & Max & Period \\
\hline \multicolumn{7}{|l|}{ Asia } \\
\hline India & 566 & 0.59 & 1.06 & -2.90 & 4.20 & $1957: 2$ to $2004: 3$ \\
\hline Indonesia & 436 & 1.01 & 2.00 & -12.52 & 20.03 & $1968: 2$ to $2004: 5$ \\
\hline Korea & 412 & 0.68 & 0.90 & -1.87 & 5.15 & $1970: 2$ to $2004: 5$ \\
\hline Srilanka & 568 & 0.63 & 1.31 & -3.57 & 8.53 & $1957: 2$ to $2004: 5$ \\
\hline Thailand & 472 & 0.42 & 0.71 & -1.63 & 4.19 & $1965: 2$ to $2004: 5$ \\
\hline Pakistan & 568 & 0.58 & 1.16 & -6.45 & 8.21 & $1957: 2$ to $2004: 5$ \\
\hline \multicolumn{7}{|l|}{ G7 } \\
\hline Canada & 568 & 0.35 & 0.39 & -0.86 & 2.59 & $1957: 2$ to $2004: 5$ \\
\hline France & 568 & 0.43 & 0.44 & -0.86 & 3.28 & $1957: 2$ to $2004: 5$ \\
\hline Germany & 568 & 0.24 & 0.34 & -1.66 & 1.71 & $1957: 2$ to $2004: 5$ \\
\hline Italy & 568 & 0.55 & 0.56 & -0.86 & 3.10 & $1957: 2$ to $2004: 5$ \\
\hline Japan & 568 & 0.31 & 0.73 & -1.56 & 4.10 & $1957: 2$ to $2004: 5$ \\
\hline UK & 568 & 0.49 & 0.64 & -1.63 & 4.22 & $1957: 2$ to $2004: 5$ \\
\hline US & 568 & 0.34 & 0.31 & -0.46 & 1.79 & $1957: 2$ to $2004: 5$ \\
\hline \multicolumn{7}{|l|}{ Latin } \\
\hline \multicolumn{7}{|l|}{ America } \\
\hline Argentina & 568 & 5.25 & 9.16 & -6.18 & 108.73 & $1957: 2$ to $2004: 5$ \\
\hline Colombia & 568 & 1.33 & 1.29 & -6.05 & 7.79 & $1957: 2$ to $2004: 5$ \\
\hline México & 568 & 1.59 & 2.07 & -1.75 & 14.38 & $1957: 2$ to $2004: 5$ \\
\hline Peru & 563 & 3.83 & 9.62 & -2.82 & 160.33 & $1957: 2$ to $2003: 12$ \\
\hline Venezuela & 567 & 1.32 & 1.89 & -5.87 & 19.28 & $1957: 2$ to $2004: 4$ \\
\hline \multicolumn{7}{|c|}{ Middle East } \\
\hline Bahrain & 314 & 0.27 & 1.35 & -4.28 & 8.55 & $1975: 8$ to $2001: 9$ \\
\hline Egypt & 565 & 0.67 & 1.73 & -7.25 & 9.46 & $1957: 2$ to $2004: 2$ \\
\hline Morocco & 568 & 0.40 & 0.99 & -3.81 & 4.06 & $1957: 2$ to $2004: 5$ \\
\hline Turkey & 424 & 3.14 & 2.73 & -6.44 & 22.08 & $1969: 2$ to $2004: 5$ \\
\hline
\end{tabular}

Monthly inflation rates are based on the log differences of consumer price index (CPI) where the data is obtained from International Financial Statistics (IFS) CD-ROM. 
Table 2. Panel A. Mean equation

\begin{tabular}{|c|c|c|c|c|c|c|c|c|c|c|c|}
\hline Country & $\mathrm{a}_{0}$ & $a_{1}$ & $\mathrm{a}_{2}$ & $a_{3}$ & $a_{4}$ & $\mathrm{~A}_{5}$ & $a_{6}$ & $a_{7}$ & $\mathrm{~d}$ & $\Theta_{1}$ & $\Theta_{2}$ \\
\hline \multicolumn{12}{|l|}{ Asia } \\
\hline India & $\begin{array}{l}4.18 \mathrm{E}-03 * * * \\
(4.92)\end{array}$ & $\begin{array}{l}0.403 * * * \\
(4.14)\end{array}$ & $\begin{array}{l}0.031 * * * \\
(7.77)\end{array}$ & & & & & & $\begin{array}{l}0.031 * * * \\
(7.77)\end{array}$ & $\begin{array}{l}0.079 \\
(0.69)\end{array}$ & $\begin{array}{l}0.231 \text { *** } \\
(6.08)\end{array}$ \\
\hline Indonesia & $\begin{array}{l}4.99 \mathrm{E}-03 * * * \\
(6.21)\end{array}$ & $\begin{array}{l}0.297 * * * \\
(4.02)\end{array}$ & $\begin{array}{l}-0.058 \\
(-0.91)\end{array}$ & $\begin{array}{c}0.115 * * * \\
(2.70)\end{array}$ & & & & & $\begin{array}{l}0.090 * * * \\
(7.49)\end{array}$ & $\begin{array}{l}0.045 \\
(0.57)\end{array}$ & $\begin{array}{l}0.303 * * * \\
(6.39)\end{array}$ \\
\hline Korea & $\begin{array}{l}2.81 \mathrm{E}-03 * * * \\
(5.15)\end{array}$ & $\begin{array}{l}0.389 * * * \\
(4.58)\end{array}$ & & & & & & & $\begin{array}{l}0.022 * * * \\
(3.26)\end{array}$ & $\begin{array}{c}0.051 \\
(0.54)\end{array}$ & $\begin{array}{l}0.246 * * * \\
(5.76)\end{array}$ \\
\hline Pakistan & $\begin{array}{l}4.78 \mathrm{E}-03 * * * \\
(5.65)\end{array}$ & $\begin{array}{l}0.118 \\
(0.90)\end{array}$ & & & & & & & $\begin{array}{c}0.045^{* * * *} \\
(7.26)\end{array}$ & $\begin{array}{l}-0.015 \\
(-0.10)\end{array}$ & $\begin{array}{l}0.197 * * * \\
(5.24)\end{array}$ \\
\hline Srilanka & $\begin{array}{l}4.71 \mathrm{E}-03 * * * \\
(7.38)\end{array}$ & $\begin{array}{l}0.023 \\
(0.40)\end{array}$ & & & & & & & $\begin{array}{c}0.062^{* * * *} \\
(19.70)\end{array}$ & $\begin{array}{l}0.249 * * * \\
(4.07)\end{array}$ & $\begin{array}{l}0.156^{* * * *} \\
(3.90)\end{array}$ \\
\hline Thailand & $\begin{array}{l}1.91 \mathrm{E}-03 * * * \\
(4.68)\end{array}$ & $\begin{array}{l}0.245^{*} \\
(1.96)\end{array}$ & $\begin{array}{l}-0.012 \\
(-0.21)\end{array}$ & $\begin{array}{c}0.155^{* * *} \\
(3.19)\end{array}$ & & & & & $\begin{array}{l}0.025 * * * \\
(5.12)\end{array}$ & $\begin{array}{l}-0.030 \\
(-0.23)\end{array}$ & $\begin{array}{l}0.232^{* * * *} \\
(5.07)\end{array}$ \\
\hline G7 & & & & & & & & & & & \\
\hline Canada & $\begin{array}{l}9.08 \mathrm{E}-04 * * * \\
(4.02)\end{array}$ & $\begin{array}{l}0.217 * * \\
(2.32)\end{array}$ & $\begin{array}{l}0.096 * \\
(1.81)\end{array}$ & $\begin{array}{l}0.076 \\
(1.59)\end{array}$ & $\begin{array}{c}0.182 * * * \\
(4.28)\end{array}$ & $\begin{array}{l}0.059 \\
(1.22)\end{array}$ & $\begin{array}{c}0.092 * * \\
(2.26)\end{array}$ & & $\begin{array}{c}0.011 * * * \\
(9.48)\end{array}$ & $\begin{array}{l}0.001 \\
(0.01)\end{array}$ & $\begin{array}{l}0.185 * * * \\
(4.91)\end{array}$ \\
\hline France & $\begin{array}{l}6.67 \mathrm{E}-04 * * * \\
(3.26)\end{array}$ & $\begin{array}{l}0.510 * * * \\
(4.39)\end{array}$ & $\begin{array}{l}0.006 \\
(0.08)\end{array}$ & $\begin{array}{c}0.244 * * * \\
(4.58)\end{array}$ & $\begin{array}{l}-0.072 \\
(-1.09)\end{array}$ & $\begin{array}{c}0.150 * * * \\
(3.25)\end{array}$ & & & $\begin{array}{c}0.009 * * * \\
(4.14)\end{array}$ & $\begin{array}{l}-0.183 \\
(-1.57)\end{array}$ & $\begin{array}{l}0.251 * * * \\
(6.57)\end{array}$ \\
\hline Germany & $\begin{array}{l}1.34 \mathrm{E}-03 * * * \\
(5.46)\end{array}$ & $\begin{array}{l}0.213 * * * \\
(3.47)\end{array}$ & $\begin{array}{c}0.157 * * * \\
(3.55)\end{array}$ & & & & & & $\begin{array}{c}0.011 * * * \\
(9.31)\end{array}$ & $\begin{array}{l}0.086 \\
(1.25)\end{array}$ & $\begin{array}{l}0.317 * * * \\
(8.90)\end{array}$ \\
\hline Italy & $\begin{array}{l}5.01 \mathrm{E}-04 * * * \\
(3.32)\end{array}$ & $\begin{array}{l}0.459 * * * \\
(4.29)\end{array}$ & $\begin{array}{c}0.119 * * \\
(2.02)\end{array}$ & $\begin{array}{l}0.072 \\
(1.40)\end{array}$ & $\begin{array}{l}0.059 \\
(1.19)\end{array}$ & $\begin{array}{l}-0.040 \\
(-0.82)\end{array}$ & $\begin{array}{l}0.038 \\
(0.82)\end{array}$ & $\begin{array}{l}0.148 * * * \\
(3.63)\end{array}$ & $\begin{array}{c}0.014^{* * * *} \\
(5.61)\end{array}$ & $\begin{array}{l}-0.205 * \\
(-1.88)\end{array}$ & $\begin{array}{l}0.204 * * * \\
(5.47)\end{array}$ \\
\hline Japan & $\begin{array}{l}1.36 \mathrm{E}-03 * * * \\
(4.22)\end{array}$ & $\begin{array}{l}0.139 * * \\
(2.04)\end{array}$ & & & & & & & $\begin{array}{l}0.027 * * * \\
(5.70)\end{array}$ & $\begin{array}{l}-0.074 \\
(-1.14)\end{array}$ & $\begin{array}{l}0.430 * * * \\
(13.68)\end{array}$ \\
\hline UK & $\begin{array}{l}2.26 \mathrm{E}-03 * * * \\
(6.87)\end{array}$ & $\begin{array}{l}0.265^{* * * *} \\
(4.10)\end{array}$ & $\begin{array}{l}0.158 * * * \\
(3.61)\end{array}$ & & & & & & $\begin{array}{c}0.022 * * * \\
(10.12)\end{array}$ & $\begin{array}{l}-0.058 \\
(-0.94)\end{array}$ & $\begin{array}{l}0.409 * * * \\
(12.46)\end{array}$ \\
\hline US & $\begin{array}{l}9.28 \mathrm{E}-04 * * * \\
(4.31)\end{array}$ & $\begin{array}{l}0.285 * * \\
(2.27)\end{array}$ & $\begin{array}{l}0.089 \\
(1.31)\end{array}$ & $\begin{array}{l}0.009 \\
(0.19)\end{array}$ & $\begin{array}{l}0.044 \\
(0.98)\end{array}$ & $\begin{array}{c}0.133 * * * \\
(2.96)\end{array}$ & $\begin{array}{l}-0.004 \\
(-0.09)\end{array}$ & $\begin{array}{c}0.146^{* * * *} \\
(3.37)\end{array}$ & $\begin{array}{c}0.007 * * * \\
(5.49)\end{array}$ & $\begin{array}{l}0.097 \\
(0.76)\end{array}$ & $\begin{array}{l}0.178 * * * \\
(4.54)\end{array}$ \\
\hline
\end{tabular}


Table 2 Panel A continued

\begin{tabular}{|c|c|c|c|c|c|c|c|c|c|c|c|}
\hline \multicolumn{12}{|l|}{$\begin{array}{l}\text { Latin } \\
\text { America }\end{array}$} \\
\hline Argentina & $\begin{array}{l}7.06 \mathrm{E}-04 \\
(1.10)\end{array}$ & $\begin{array}{l}0.119 * \\
(1.87)\end{array}$ & $\begin{array}{c}0.375 * * * \\
(6.99)\end{array}$ & $\begin{array}{l}0.141 * * * \\
(2.81)\end{array}$ & $\begin{array}{l}-0.032 \\
(-0.77)\end{array}$ & $\begin{array}{l}0.055 \\
(1.35)\end{array}$ & $\begin{array}{c}0.129 * * * \\
(3.35)\end{array}$ & $\begin{array}{l}0.096 * * * \\
(2.58)\end{array}$ & $\begin{array}{l}0.419 * * * \\
(9.86)\end{array}$ & $\begin{array}{l}0.373 * * * \\
(5.87)\end{array}$ & $\begin{array}{l}0.188 * * * \\
(8.02)\end{array}$ \\
\hline Colombia & $\begin{array}{l}5.25 \mathrm{E}-03 * * * \\
(6.41)\end{array}$ & $\begin{array}{l}0.591 * * * \\
(10.80)\end{array}$ & & & & & & & $\begin{array}{l}0.035 * * * \\
(5.35)\end{array}$ & $\begin{array}{l}0.034 \\
(0.51)\end{array}$ & $\begin{array}{l}0.263 * * * \\
(7.17)\end{array}$ \\
\hline Mexico & $\begin{array}{l}2.55 \mathrm{E}-03 * * * \\
(5.26)\end{array}$ & $\begin{array}{l}0.602 * * * \\
(5.34)\end{array}$ & $\begin{array}{l}0.203^{*} \\
(1.93)\end{array}$ & & & & & & $\begin{array}{l}0.048 * * * \\
(11.52)\end{array}$ & $\begin{array}{l}0.095 \\
(0.75)\end{array}$ & $\begin{array}{l}0.185^{* * * *} \\
(5.67)\end{array}$ \\
\hline Peru & $\begin{array}{l}2.91 \mathrm{E}-03 * * * \\
(3.98)\end{array}$ & $\begin{array}{l}-0.178 \\
(-1.04)\end{array}$ & $\begin{array}{l}0.346^{* * *} \\
(4.16)\end{array}$ & $\begin{array}{c}0.234 * * * \\
(3.85)\end{array}$ & $\begin{array}{l}0.293 * * * \\
(5.69)\end{array}$ & $\begin{array}{l}0.093 * \\
(1.95)\end{array}$ & & & $\begin{array}{l}-0.028 \\
(-0.97)\end{array}$ & $\begin{array}{l}0.531 * * * \\
(3.28)\end{array}$ & $\begin{array}{l}0.076^{* * * *} \\
(2.91)\end{array}$ \\
\hline Venezuela & $\begin{array}{l}1.57 \mathrm{E}-03 * * * \\
(4.43)\end{array}$ & $\begin{array}{l}0.471 * * * \\
(4.61)\end{array}$ & $\begin{array}{l}0.081 \\
(1.20)\end{array}$ & $\begin{array}{c}0.117 * * \\
(2.31)\end{array}$ & $\begin{array}{l}0.053 \\
(1.23)\end{array}$ & $\begin{array}{c}0.120 * * * \\
(2.73)\end{array}$ & & & $\begin{array}{c}0.071 * * * \\
(6.16)\end{array}$ & $\begin{array}{l}-0.057 \\
(-0.56)\end{array}$ & $\begin{array}{l}0.057 \\
(1.53)\end{array}$ \\
\hline \multicolumn{12}{|l|}{ Middle } \\
\hline Bahrain & $\begin{array}{c}6.26 \mathrm{E}-04 \\
(1.56)\end{array}$ & $\begin{array}{l}-0.066 \\
(-0.64)\end{array}$ & & & & & & & $\begin{array}{c}0.064 * * * \\
(8.30)\end{array}$ & $\begin{array}{l}-0.192 \\
(-1.57)\end{array}$ & $\begin{array}{l}0.117 * * * \\
(2.85)\end{array}$ \\
\hline Egypt & $\begin{array}{l}2.65 \mathrm{E}-03 * * * \\
(10.21)\end{array}$ & $\begin{array}{l}-0.046 \\
(-1.38)\end{array}$ & & & & & & & $\begin{array}{c}0.092 * * * \\
(24.69)\end{array}$ & $\begin{array}{l}0.049 \\
(0.98)\end{array}$ & $\begin{array}{l}0.174 * * * \\
(5.48)\end{array}$ \\
\hline Morocco & $\begin{array}{l}3.48 \mathrm{E}-03 * * * \\
(5.87)\end{array}$ & $\begin{array}{l}0.239 * * * \\
(3.75)\end{array}$ & & & & & & & $\begin{array}{c}0.025 * * * \\
(6.50)\end{array}$ & $\begin{array}{l}0.188 * * * \\
(2.86)\end{array}$ & $\begin{array}{l}0.215^{* * * *} \\
(6.24)\end{array}$ \\
\hline Turkey & $\begin{array}{l}1.81 \mathrm{E}-02 * * * \\
(7.56)\end{array}$ & $\begin{array}{l}0.403 * * * \\
(6.35)\end{array}$ & & & & & & & $\begin{array}{c}0.117 * * * \\
(12.51)\end{array}$ & $\begin{array}{l}0.018 \\
(0.25)\end{array}$ & $\begin{array}{l}0.338^{* * * *} \\
(7.93)\end{array}$ \\
\hline
\end{tabular}


Panel B. PGARCH equation

\begin{tabular}{|c|c|c|c|c|c|}
\hline Country & $\alpha_{0}$ & $\alpha_{1}$ & $\Psi$ & $\beta_{1}$ & $\log \mathrm{L}$ \\
\hline \multicolumn{6}{|l|}{ Asia } \\
\hline India & $\begin{array}{c}1.04 \mathrm{E}-05^{* * *} \\
(2.75)\end{array}$ & $\begin{array}{c}0.514 * * * \\
(3.81)\end{array}$ & $\begin{array}{c}-0.199 * * \\
(-2.13)\end{array}$ & $\begin{array}{c}0.436^{* * *} \\
(3.26)\end{array}$ & 1811.07 \\
\hline Indonesia & $\begin{array}{c}2.19 \mathrm{E}-05^{*} \\
(1.72)\end{array}$ & $\begin{array}{c}0.378 * * \\
(2.31)\end{array}$ & $\begin{array}{l}-0.096 \\
(-0.73)\end{array}$ & $\begin{array}{c}0.501 * * * \\
(2.78)\end{array}$ & 1322.69 \\
\hline Korea & $\begin{array}{c}2.06 \mathrm{E}-06^{* * * *} \\
(2.60)\end{array}$ & $\begin{array}{c}0.206^{* * *} \\
(4.04)\end{array}$ & $\begin{array}{l}-0.105 \\
(-0.63)\end{array}$ & $\begin{array}{c}0.782 * * * \\
(14.48)\end{array}$ & 1427.04 \\
\hline Pakistan & $\begin{array}{c}2.43 \mathrm{E}-06 \\
(0.60)\end{array}$ & $\begin{array}{c}0.069 * * * \\
(3.14)\end{array}$ & $\begin{array}{l}-0.263 \\
(-1.09)\end{array}$ & $\begin{array}{c}0.899 * * * \\
(12.92)\end{array}$ & 1807.51 \\
\hline Srilanka & $\begin{array}{c}2.03 \mathrm{E}-07 \\
(1.47)\end{array}$ & $\begin{array}{c}0.028 * * * \\
(3.03)\end{array}$ & $\begin{array}{l}-0.192 \\
(-1.52)\end{array}$ & $\begin{array}{c}0.969 * * * \\
(114.16)\end{array}$ & 1745.65 \\
\hline Thailand & $\begin{array}{c}9.93 \mathrm{E}-07 * * \\
(2.11)\end{array}$ & $\begin{array}{c}0.047^{* *} \\
(2.29)\end{array}$ & $\begin{array}{l}-0.537 \\
(-1.47)\end{array}$ & $\begin{array}{c}0.905 * * * \\
(31.92)\end{array}$ & 1699.69 \\
\hline \multicolumn{6}{|l|}{ G7 } \\
\hline Canada & $\begin{array}{c}2.01 \mathrm{E}-06^{* *} \\
(2.03)\end{array}$ & $\begin{array}{c}0.526^{* * *} \\
(3.80)\end{array}$ & $\begin{array}{l}-0.074 \\
(-0.70)\end{array}$ & $\begin{array}{c}0.401 * * * \\
(3.85)\end{array}$ & 2376.35 \\
\hline France & $\begin{array}{c}1.65 \mathrm{E}-07 \\
(1.20)\end{array}$ & $\begin{array}{c}0.120^{*} \\
(1.72)\end{array}$ & $\begin{array}{l}-0.055 \\
(-0.81)\end{array}$ & $\begin{array}{c}0.877 * * * \\
(12.51)\end{array}$ & 2470.08 \\
\hline Germany & $\begin{array}{c}2.16 \mathrm{E}-06^{* *} \\
(2.34)\end{array}$ & $\begin{array}{c}0.560 * * * \\
(2.64)\end{array}$ & $\begin{array}{l}-0.033 \\
(-0.30)\end{array}$ & $\begin{array}{c}0.352 * * \\
(2.23)\end{array}$ & 2418.54 \\
\hline Italy & $\begin{array}{c}2.32 \mathrm{E}-08 \\
(0.62)\end{array}$ & $\begin{array}{c}0.099 * * * \\
(2.80)\end{array}$ & $\begin{array}{l}-0.179 \\
(-1.38)\end{array}$ & $\begin{array}{c}0.897 * * * \\
(23.34)\end{array}$ & 2411.97 \\
\hline Japan & $\begin{array}{c}1.58 \mathrm{E}-06 \\
(1.15)\end{array}$ & $\begin{array}{l}0.227 \\
(1.53)\end{array}$ & $\begin{array}{l}-0.009 \\
(-0.11)\end{array}$ & $\begin{array}{c}0.763 * * * \\
(5.06)\end{array}$ & 2045.02 \\
\hline UK & $\begin{array}{c}3.75 \mathrm{E}-07 * * \\
(2.53)\end{array}$ & $\begin{array}{c}0.009 * * * \\
(2.77)\end{array}$ & $\begin{array}{c}-1.00 * * * \\
(-134.6)\end{array}$ & $\begin{array}{c}0.960 * * * \\
(84.00)\end{array}$ & 2185.33 \\
\hline US & $\begin{array}{c}3.41 \mathrm{E}-07 * * \\
(2.10)\end{array}$ & $\begin{array}{c}0.085^{* *} \\
(2.39)\end{array}$ & $\begin{array}{l}-0.189 \\
(-1.10)\end{array}$ & $\begin{array}{c}0.839 * * * \\
(14.22)\end{array}$ & 2585.60 \\
\hline \multicolumn{6}{|c|}{ Latin America } \\
\hline Argentina & $\begin{array}{c}3.61 \mathrm{E}-06^{* * * *} \\
(3.48)\end{array}$ & $\begin{array}{c}0.195^{* * *} * \\
(6.37)\end{array}$ & $\begin{array}{c}-0.517 * * * \\
(-5.00)\end{array}$ & $\begin{array}{c}0.750 * * * \\
(28.19)\end{array}$ & 1292.20 \\
\hline Colombia & $\begin{array}{c}5.32 \mathrm{E}-07 \\
(0.94)\end{array}$ & $\begin{array}{c}0.076^{* * *} \\
(3.63)\end{array}$ & $\begin{array}{c}-0.287 * * \\
(-2.29)\end{array}$ & $\begin{array}{c}0.915 * * * \\
(36.13)\end{array}$ & 1830.18 \\
\hline Mexico & $\begin{array}{c}1.46 \mathrm{E}-05^{* * * *} \\
(6.48)\end{array}$ & $\begin{array}{c}0.436 * * * \\
(6.43)\end{array}$ & $\begin{array}{c}-0.624 * * * \\
(-5.73)\end{array}$ & $\begin{array}{c}0.382 * * * \\
(6.47)\end{array}$ & 1904.56 \\
\hline Peru & $\begin{array}{c}8.60 \mathrm{E}-06^{* * * *} \\
(4.45)\end{array}$ & $\begin{array}{c}0.145^{* *} \\
(2.43)\end{array}$ & $\begin{array}{c}-0.999 * * \\
(-2.45)\end{array}$ & $\begin{array}{c}0.705 * * * \\
(41.16)\end{array}$ & 1463.81 \\
\hline Venezuela & $\begin{array}{c}6.40 \mathrm{E}-06^{* * * *} \\
(3.69)\end{array}$ & $\begin{array}{c}0.377 * * * \\
(4.37)\end{array}$ & $\begin{array}{c}-0.399 * * * \\
(-4.26)\end{array}$ & $\begin{array}{c}0.561 * * * \\
(6.51)\end{array}$ & 1877.36 \\
\hline \multicolumn{6}{|l|}{ Middle East } \\
\hline Bahrain & $\begin{array}{c}2.06 \mathrm{E}-05^{* * * *} \\
(2.88)\end{array}$ & $\begin{array}{c}0.646^{* * *} * \\
(5.36)\end{array}$ & $\begin{array}{l}-0.101 \\
(-0.86)\end{array}$ & $\begin{array}{c}0.338 * * * \\
(2.94)\end{array}$ & 951.72 \\
\hline Egypt & $\begin{array}{c}4.22 \mathrm{E}-07 * * \\
(2.19)\end{array}$ & $\begin{array}{c}0.218^{* * *} \\
(8.75)\end{array}$ & $\begin{array}{c}-0.150 * * * \\
(-2.73)\end{array}$ & $\begin{array}{c}0.773 * * * \\
(30.56)\end{array}$ & 1662.89 \\
\hline Morocco & $\begin{array}{c}3.36 \mathrm{E}-06 \\
(1.35)\end{array}$ & $\begin{array}{l}0.101^{*} \\
(1.73)\end{array}$ & $\begin{array}{c}-0.638 * * \\
(-2.46)\end{array}$ & $\begin{array}{c}0.847 * * * \\
(11.07)\end{array}$ & 1848.55 \\
\hline Turkey & $\begin{array}{c}3.83 \mathrm{E}-05 \\
(1.41)\end{array}$ & $\begin{array}{l}0.108^{*} \\
(1.87)\end{array}$ & $\begin{array}{l}-0.063 \\
(-0.36)\end{array}$ & $\begin{array}{c}0.799 * * * \\
(7.36)\end{array}$ & 1006.49 \\
\hline
\end{tabular}

The specification of the mean equation in Panel A is given by equation (1) and the PGARCH is described in equation (2). The asterisks $* * *, * *, *$, indicate $1 \%, 5 \%$, and $10 \%$ significance levels, respectively. 
Table 3. Granger Causality Tests

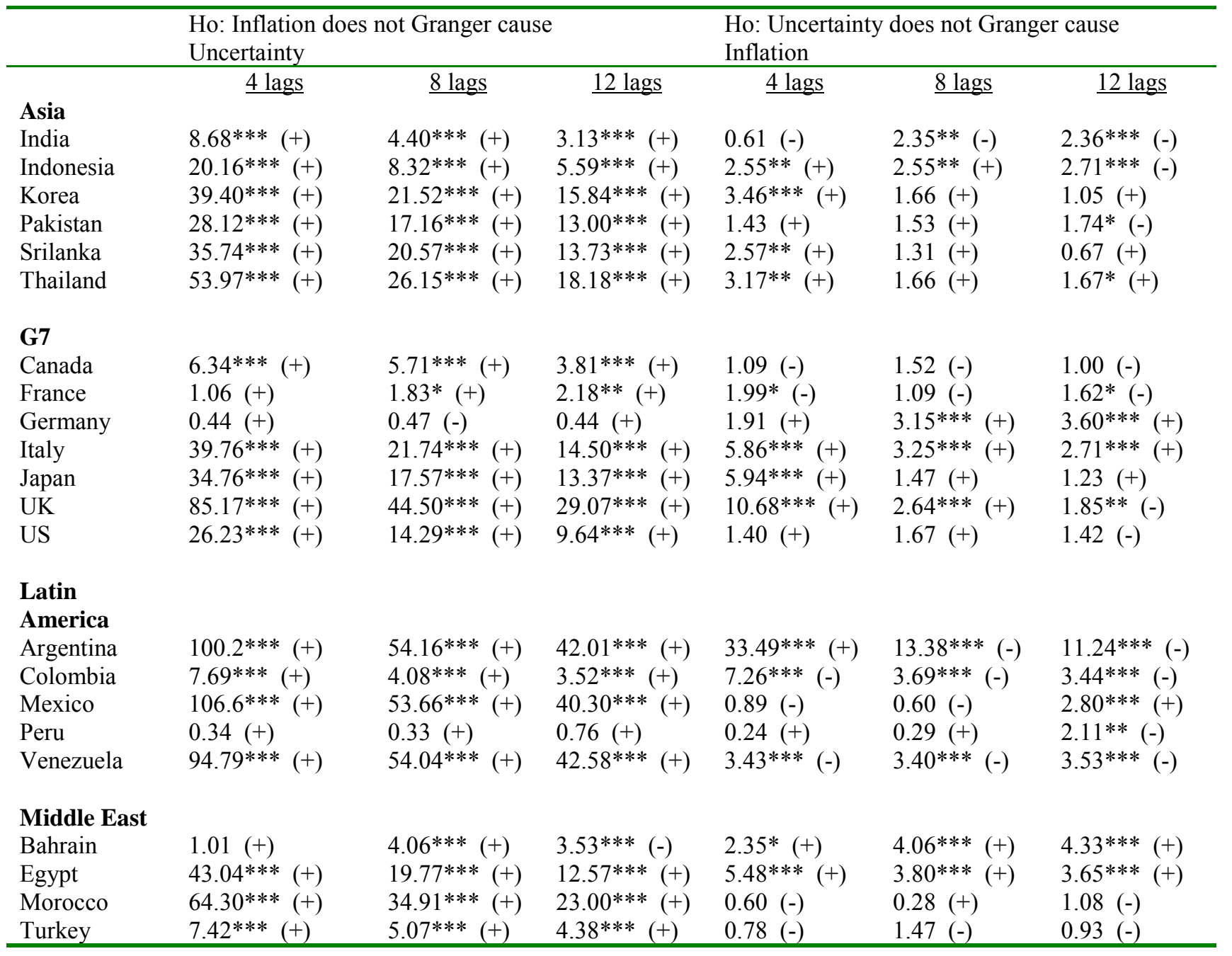

The results are based on the bivariate VAR specifications in equations (3) and (4). The asterisks $* * *, * *, *$, indicate $1 \%, 5 \%$, and $10 \%$ significance levels, respectively. The signs $(+)$ and $(-)$ are based on the sum of the coefficients estimated and correspond with each hypothesis. For example, the value of 26.23 for the U.S. is the value of statistic that tests whether c1, c2, c2 and $\mathrm{c} 4$ are jointly significant. The positive sign $(+)$ indicates that the sum of the estimated coefficients, $c_{1}+c_{2}+c_{3}+c_{4}$, in equation (3) is positive. 